Vol 12, Issue 1, 2019

\title{
PHYTOCHEMICAL SCREENING AND HISTOLOGY APPEARANCE OF ACUTE ORAL TOXICITY STUDY ON ETHANOL EXTRACT OF PSIDIUM GUAJAVA LINN. FRUIT IN MICE
}

\author{
NUR ATIK $^{1 *}$, ISKANDAR MUDA ${ }^{2}$, ANDRI REZA RAHMADI ${ }^{3}$, ACHADIYANI ${ }^{1}$, DIAH DHIANAWATY DJUNAEDY ${ }^{1}$ \\ ${ }^{1}$ Department of Biomedical Sciences, Faculty of Medicine, Universitas Padjadjaran, Bandung, Indonesia. ${ }^{2}$ Graduate School of Biomedical \\ Sciences Master Program, Faculty of Medicine, Universitas Padjadjaran, Indonesia. ${ }^{3}$ Department of Internal Medicine, Faculty of Medicine, \\ Universitas Padjadjaran, Dr. Hasan Sadikin General Hospital, Indonesia. Email: n.atik@unpad.ac.id
}

Received: 05 October 2018, Revised and Accepted: 20 November 2018

ABSTRACT

Objective: The main objectives of the research are to investigate the phytochemical screening, histology appearance, and safety of acute oral toxicity study on the extract of the fruit of Psidium guajava Linn. in mice.

Methods: Mice that were administered by oral feeding with different and controlled dose were divided into three groups, with dose limits of both 2000 and $5000 \mathrm{mg} / \mathrm{kg}$ b.w. We analyzed the P. guajava Linn. extract with specific methods before treating the subject. The methods were followed with acute oral toxicity study of Up-and-Down Procedure Organization for Economic and Development 425. The mice were then observed for signs and symptoms of toxicity. In addition, toxicity in the liver and kidney was analyzed through histology observation.

Results: Phytochemical screening revealed the presence of flavonoids, quinone, triterpenoid/steroid, tannins and saponins, and the absence of alkaloids. We found that the treatment with 2000 and $5000 \mathrm{mg} / \mathrm{kg}$ b.w. of the extract did not show any differences in body weight changes, number of hepatocyte in liver, and podocyte in kidney compared with control $\left({ }^{*} p>0.05\right)$. Moreover, we noticed all mice lived and were healthy during observation.

Conclusion: Our finding indicates that the extract of the fruit of P. guajava Linn. is safe and it was not toxic to the liver and kidney.

Keywords: Phytochemical screening, Histology, Acute toxicity, Psidium guajava Linn.

(C) 2019 The Authors. Published by Innovare Academic Sciences Pvt Ltd. This is an open access article under the CC BY license (http://creativecommons. org/licenses/by/4. 0/) DOI: http://dx.doi.org/10.22159/ajpcr.2019.v12i1.30118

\section{INTRODUCTION}

Guava (Psidium guajava Linn.), a part of Myrtaceae family, is a widespread tropical and subtropical plant with a long history of traditional usage. Several fragments of guava (P. guajava Linn.) have a lot of medicinal properties that were not only consumed as food but also traditional medicine to remedy various ailments [1]

There has been a long history in the utilization of traditional medicine in half of the world, and it circumscribes a simple, reachable, and affordable source of treatment [2]. Some researchers have revealed that the depletion of fruits, vegetables, and seed can be advantageous to prevent risk factors of several ailments related to the circumstance of chronic disorders, and for many other purposes due to their bioactive compounds $[3,4]$. Therapies have shown auspicious potential agents with several benefits in herbal products. However, many herbal medicine utilizations which remain untested are poorly monitored or worse are not monitored at all. The limited information of their action mechanism, potential harmful reactions, contraindications, and interactions with existing common pharmaceuticals encourage many researchers to promote the safety and rational utilization of these agents [5].

In pharmacology, it is very important to perform toxicity test for new drug candidates. The test was conducted to evaluate the safety or hazards of several substances including industrial chemicals, pharmaceutical, and consumer care products. The Organization for Economic and Development (OECD) introduced acute toxicity as the advance effect occurring in a short time of oral administration after a simple or multiple doses is given [6-8].

Up-and-Down Procedure (UDP) of OECD 425 is one of the methods for $\mathrm{LD}_{50}$ acute toxicity test. UDP permits to reduce the number of animals substantially, which is required for determining $\mathrm{LD}_{50}$ values as well as $\mathrm{ED}_{50}$ values of a variety of other listings. Animals in the UDP methods are observed individually at least once during the first $30 \mathrm{~min}$ after dosing, and periodically during the first $24 \mathrm{~h}-14$ days. All observations including toxic signs, body weight, and pathology are systematically recorded, with individual records being maintained for each animal $[7,9]$. The aim of our recent study is to know the phytochemical screening and histology appearance of acute oral toxicity, and sign and symptom of toxicity after P. guajava Linn. extract treatment to the mice.

\section{MATERIALS AND METHODS}

\section{Preparation of plant extract}

Fruit samples were collected from guava trees grown at Dukuh Waluh Village, Purwokerto, Central Java, Indonesia. Random ripe fruit samples were collected into plastic bags with appropriate labeling and were stored in an ice cooler box to be transported to the laboratory for extraction. The fruit samples were substantiated by Central Laboratory of Universitas Padjadjaran.

\section{Extraction methods for guava fruits}

The fruit samples were washed in tap water and were placed into a blender to be grounded. $96 \%$ ethanol solvent was used for maceration extraction procedure. Then, the filtering was conducted using a funnel buncher. The filtral produced from the filtration was concentrated using a rotary evaporator at $40^{\circ} \mathrm{C}$ to obtain the result of concentrated extract and was suspended using distilled water as needed. The extract was afterward collected and stored at $4^{\circ} \mathrm{C}$ until use.

\section{Phytochemical screening}

Chemical test for the screening of bioactive chemical constituents in the guava was carried out with extracts using a guide of phytochemical methods as described by Harborne [10]. The extract was chemically 
tested for the presence of flavonoids, quinone, triterpenoid/steroid, alkaloids, tannins, and saponins.

\section{Experimental animals}

A total of 12 healthy female albino mice of the Swiss Webster that weighed 20-30 g that were 8-12 weeks old and that were nulliparous and nonpregnant were selected as the subject. The mice were procured from the Laboratory of Pharmacology and Therapy, Universitas Padjadjaran. The mice were housed in cages in a temperature-controlled room $\left(22 \pm 3^{\circ} \mathrm{C}\right)$ and were provided with conventional rodent laboratory fed an unlimited supply of drinking water ad libitum. The procedures taken passed the Ethical Clearance from Health Research Ethics Committee (No. 1104/UN6.C.10/PN/2017), Universitas Padjadjaran.

\section{Acute oral toxicity test}

The mice were divided into three sets that were administered by oral feeding to different sets, at dose limits of both 2000 and $5000 \mathrm{mg} / \mathrm{kg}$ b.w. and control. All mice were observed for toxic signs, body weight, and mortality for 14 days for qualitative data.

Group 1 served as a control and received distilled water. Group 2 received a dose limit of $2000 \mathrm{mg} / \mathrm{kg}$ b.w. of fruit extract $(0.2 \mathrm{ml} / \mathrm{kg}$ b.w., p.o). Each mouse was given one dose test. If it survives, another four mice were given a dose sequentially. If three or more animal survives, the test was proceeded to a dose limit of $5000 \mathrm{mg} / \mathrm{kg}$ b.w. Group 3 received a dose limit of $5000 \mathrm{mg} / \mathrm{kg}$ b.w. of fruit $(0.2 \mathrm{ml} / \mathrm{kg}$ b.w., p.o). If the mouse survives, another two mice were given a dose sequentially. If both mice survive, the $\mathrm{LD}_{50}$ was given more than the limit dose [7].

\section{Histology analysis}

The mice were sacrificed, and afterward, liver and kidney collection was conducted. The organs were fixed with $3 \%(\mathrm{w} / \mathrm{v})$ paraformaldehyde and were processed as previously described. We performed hematoxylineosin (HE) staining according to the previous methods [11-13].

\section{Statistical analysis}

Quantitative data were expressed as mean \pm SD. The data were determined and analyzed using one-way ANOVA. The statistical significance was accepted if $\mathrm{p}<0.05$.

\section{RESULTS}

\section{Phytochemical analysis}

Phytochemical screening is an early stage to give a scheme of compound classification in plant samples. Table 1 shows the summarized phytochemical screening of chemical constituents of P. guajava Linn.

Table 1: Phytochemistry of P. guajava Linn. Extract

\begin{tabular}{lll}
\hline Constituents & Qualitative tests & Result \\
\hline Flavonoids & $\mathrm{HCl} 2 \mathrm{M}$ and Amyl alcohol & + \\
Quinone & $\mathrm{NaOH} \mathrm{30 \%}$ & + \\
Triterpenoid/steroid & Acetic acid anhydride and $\mathrm{H}_{2} \mathrm{SO}_{4}$ & + \\
Alkaloid & Dragendorff & - \\
Tannins & $\mathrm{FeCl}_{3}$ & + \\
Saponins & $\mathrm{H}_{2} \mathrm{O}$ & + \\
\hline
\end{tabular}

(+) present and (-) absent fruit extract understudy on a qualitative basis. Phytochemical analysis revealed the presence of flavonoids, quinone, triterpenoid/steroid, tannins, and saponins in the P. guajava Linn. and the absence of alkaloids.

\section{Clinical observations}

Assessment of animal behavior was performed by general observation to the animals on a daily basis from the first dosing treatment until the end of the study. The recorded changes or abnormalities could be indications of toxicity. We found that there were no significant changes in behavior on all mice from different treatments. In addition, all mice survived during observation, starting from treatment until the end of observation (Table 2).

\section{Body weight changes}

Body weight is an important parameter to monitor the animal's health status. Weight loss is frequently used as the first indicator of the adverse effect of the drugs. The dosage is considered toxic if the drug causes $10 \%$ or more body weight reduction. This condition could be taken as a sign of toxicity even though there are no other changes occurred [9]. We found that all of the mice from the treatment groups did not show any significant decrease in body weight from 0 to 14 days (Fig. 1). Furthermore, there was no significant difference between control and treatment group $(\mathrm{p}=0.074)$ (Table 3$)$.

Body weights of mice from each group observed before treatment until 14 days.

\section{Histology analysis}

We proceeded our observation in the liver and kidney to know the toxicity effect after the treatment. All the tissue sections collected from the liver and kidney were observed under the microscope to know the number of hepatocytes and podocytes. We found that the number of normal hepatocytes was not significantly different $(p=0.630)$ between control and treatment group (Tables 4 and 5). Similar results were also found when we analyzed the number of podocytes from glomerulus area in the kidney ( $\mathrm{p}=0.553)$ (Tables 6 and 7). In addition, there was no difference between hepatocytes and podocytes morphology in the control and treatment group (Fig. 2).

Morphological analysis of liver (A, B, and C) and kidney (D, E, and F) by HE-stained paraffin sections from control and treatment mice (Bar $50 \mu \mathrm{m})$. The hepatocytes and podocytes were counted and compared from each group ( $\mathrm{G}$ and $\mathrm{H}$, respectively). CV: Central vein. H: Hepatocyte. G: Glomerulus; P: Podocyte; NS: Not Significant. Bar $50 \mu \mathrm{m}$.

\section{DISCUSSION}

This study showed phytochemical screening of the presence of flavonoids, quinone, triterpenoid/steroid, tannins, and saponin in P. guajava Linn. extract. All these bioactive compounds have some beneficial effects in remedying including antidiarrhea, antimicrobial, acne lesion, and thrombocytopenia, to name a few [1,14-16].

Toxicity test procedures measured several parameters such as body weight, clinical signs, and symptoms. The observation was necessary for determining the $\mathrm{LD}_{50}$. Our study showed that there were no toxic

Table 2: Clinical observation

\begin{tabular}{|c|c|c|c|c|c|c|c|c|}
\hline Group & Toxic Signs & & Group & Toxic Signs & & Group & Toxic Signs & \\
\hline \multirow[t]{7}{*}{ Control } & Cyanosis & - & Dose 1 & Cyanosis & - & Dose 2 & Cyanosis & - \\
\hline & Tremor & - & & Tremor & - & & Tremor & - \\
\hline & Salivation & - & & Salivation & - & & Salivation & - \\
\hline & Piloerection & - & & Piloerection & - & & Piloerection & - \\
\hline & Feces & - & & Feces & - & & Feces & - \\
\hline & Vomiting & - & & Vomiting & - & & Vomiting & - \\
\hline & Death & - & & Death & - & & Death & - \\
\hline
\end{tabular}

(-) normal. Control=distillated water; dose $1=2000 \mathrm{mg} / \mathrm{kg}$ b.w.; dose $2=5000 \mathrm{mg} / \mathrm{kg}$ b.w. 


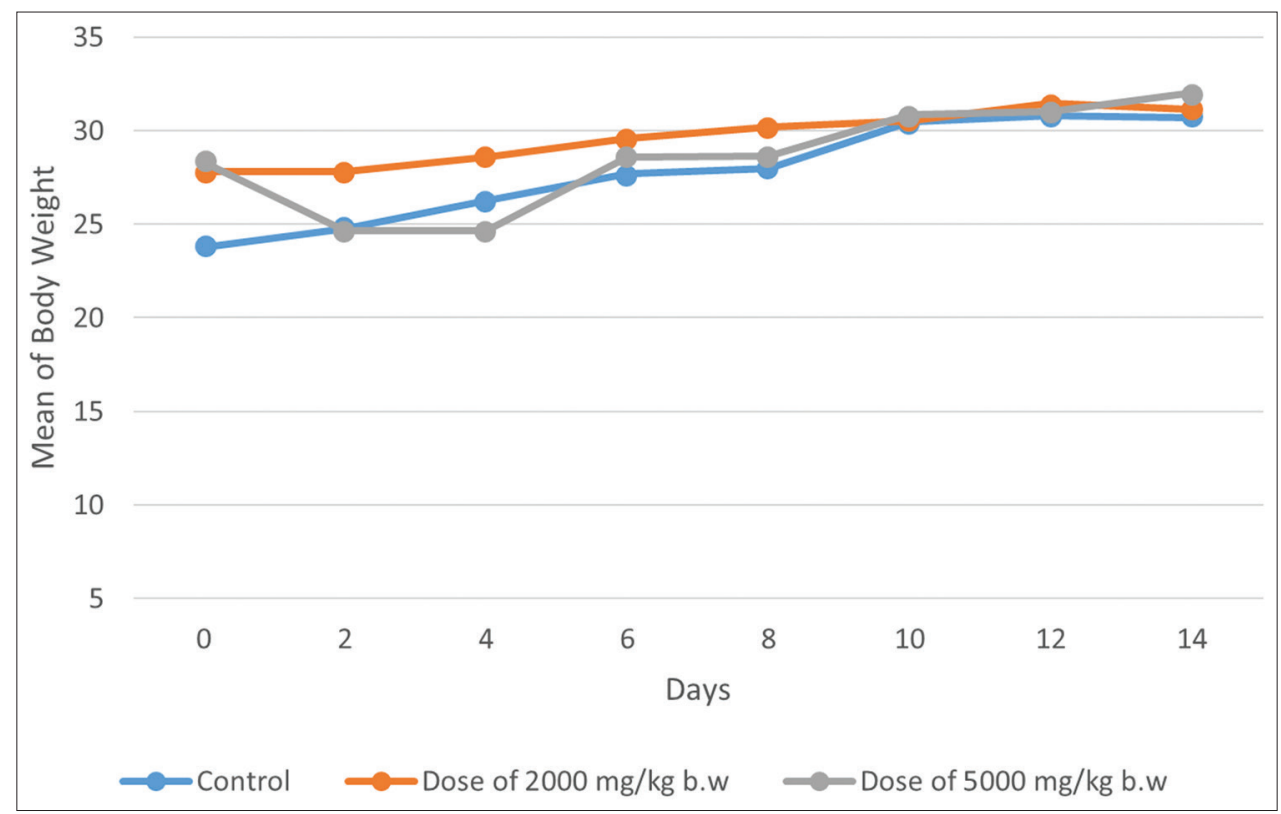

Fig. 1: Body weight observation
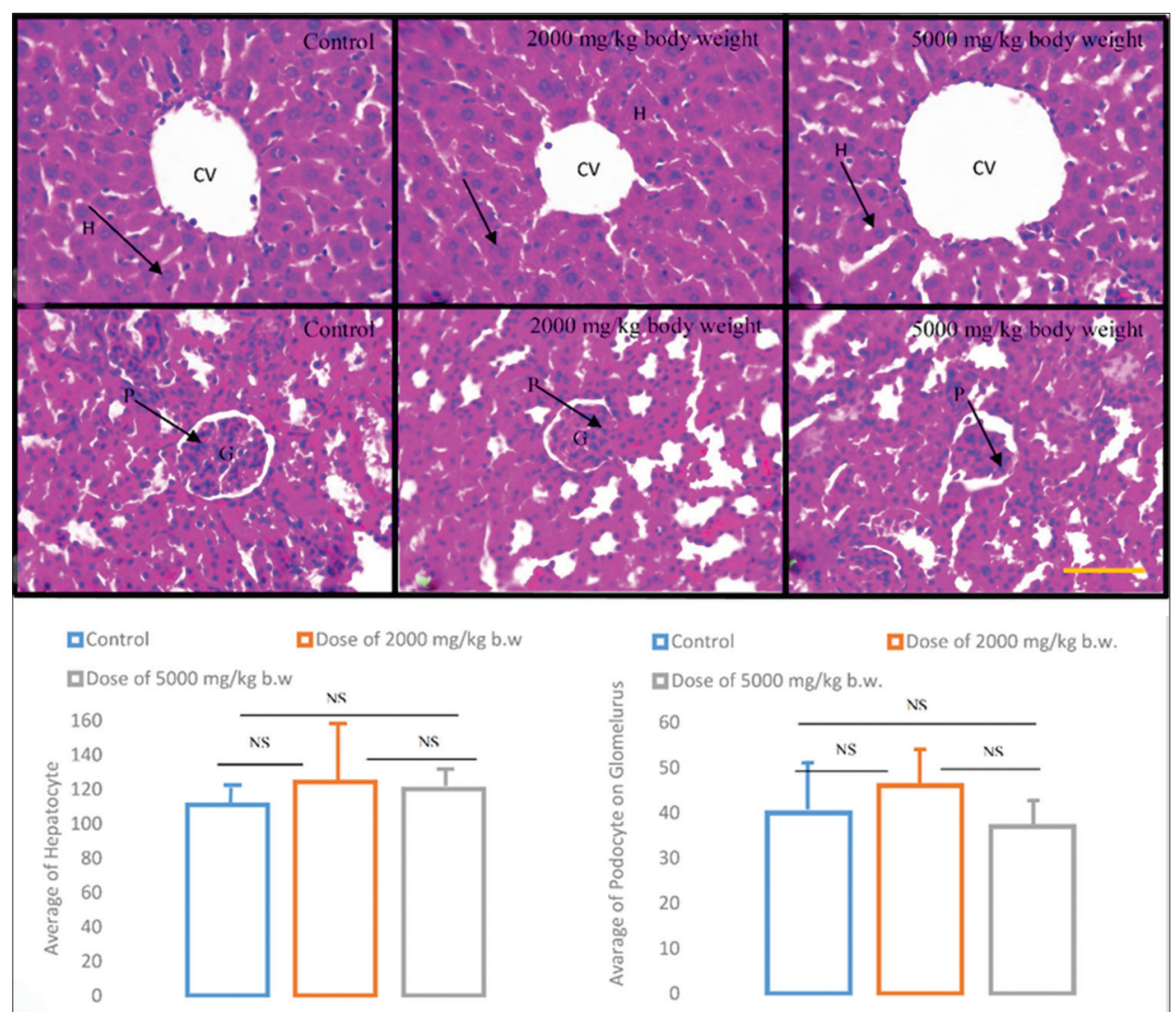

Fig. 2: Histology of the liver and kidney

Table 3: Statistical analysis of body weight

\begin{tabular}{lcc}
\hline $\begin{array}{l}\text { Treatment } \\
\text { group }\end{array}$ & Mean \pm SD & p value \\
\hline Control & $27.60 \pm 2.69$ & \\
Dose 1 & $29.60 \pm 1.18$ & 0.074 \\
Dose 2 & $28.20 \pm 2.90$ & \\
\hline Control=distillated water; dose $1=2000 \mathrm{mg} / \mathrm{kg}$ b.w.; dose 2=5000 mg/kg b.w.
\end{tabular}

Table 4: Anova test of hepatocytes number

\begin{tabular}{llc}
\hline $\begin{array}{l}\text { Treatment } \\
\text { group }\end{array}$ & Mean \pm SD & p value \\
\hline Control & $111.00 \pm 9.41$ & \\
Dose 1 & $123.40 \pm 24.92$ & 0.630 \\
Dose 2 & $20.67 \pm 16.92$ & \\
\hline Control=distillated water; dose $1=2000 \mathrm{mg} / \mathrm{kg}$ b.w.; dose 2=5000 $\mathrm{mg} / \mathrm{kg}$ b.w.
\end{tabular}


Table 5: Post hoc test of hepatocytes number

\begin{tabular}{ll}
\hline Treatment group & p value \\
\hline Control versus dose 1 & 0.361 \\
Control versus dose 2 & 0.527 \\
Dose 1 versus dose 2 & 0.85 \\
\hline
\end{tabular}

Control=distillated water; dose $1=2000 \mathrm{mg} / \mathrm{kg}$ b.w.; dose $2=5000 \mathrm{mg} / \mathrm{kg}$ b.w.

Table 6: ANOVA test of podocytes number

\begin{tabular}{llc}
\hline Treatment group & (Mean \pm SD) & p value \\
\hline Control & $39.75 \pm 19.20$ & \\
Dose 1 & $46.20 \pm 5.16$ & 0.553 \\
Dose 2 & $37.33 \pm 3.05$ & \\
\hline Control=distillated water; dose $1=2000 \mathrm{mg} / \mathrm{kg} b \cdot \mathrm{w} \cdot$ dose $2=5000 \mathrm{mg} / \mathrm{kg} \mathrm{b} \cdot \mathrm{w}$
\end{tabular}

Table 7: Post hoc test of podocytes number

\begin{tabular}{ll}
\hline Treatment group & p value \\
\hline Control dose 1 & 0.432 \\
Control dose 2 & 0.793 \\
Dose 1 dose 2 & 0.327 \\
\hline
\end{tabular}

Control=distillated water; dose $1=2000 \mathrm{mg} / \mathrm{kg}$ b.w.; dose $2=5000 \mathrm{mg} / \mathrm{kg}$ b.w.

signs and changes found on body weight in mice from treatment group within $4 \mathrm{~h}, 48 \mathrm{~h}, 7$ days, and 14 days after treatment of guava fruit (P. guajava Linn.) extract, and there was no significant difference compared to control group. Previous studies also showed no differences in body weight, behaviors, and symptoms between control group that received distilled water compared to treatment groups that received guava leaves extract at the dose of 200, 1000, 2000, 2500, 5000, and $20,000 \mathrm{mg} / \mathrm{kg} /$ day for 14 days to 6 months $[17,18]$.

Histological examination of the liver in the control group and the treatment group showed that there was no difference in the number of the hepatocyte. It may be because P. guajava plant has a hepatoprotective activity due to the bioactive compound in P. guajava Linn. [19]. P. guajava Linn. contains total polyphenols and dietary fiber such as flavonoids that may exert an antioxidant effect as radical-scavenging activity $[20,21]$. P. guajava Linn. also contains saponin that serves to reduce blood cholesterol levels. These substances could protect the stability of liver metabolic process [22]. Moreover, our previous data showed that there was no disturbance in the liver function on a biochemical test of liver function including alanine aminotransferase, aspartate aminotransferase, and total bilirubin at doses of 2000 and $5000 \mathrm{mg} / \mathrm{kg}$ body weight of the P. guajava Linn. extract [23,24].

Histological examination of the kidney in the control and treatment group showed no differences in the number of podocytes. The previous study mentions that the active content of guava fruit extract had kidney protective properties on ethanol extract of P. guajava Linn. in miceinduced doxorubicin $[25,26]$. During a development of a new drug, there could be a change in renal function which raises the question of nephrotoxicity. Sometimes it showed a positive effect on the kidneys; however, the incidence with negative effects is unavoidable $[27,28]$.

\section{CONCLUSION}

Our finding indicates that the P. guajava Linn. fruit extract contains some bioactive compounds that have a medicinal effect. Toxicity test with a dose limit of 2000 and $5000 \mathrm{mg} / \mathrm{kg}$ b.w. of the extract administration showed that it is nontoxic.

\section{ACKNOWLEDGMENT}

The authors would like to thank the Internal Grant of Universitas Padjadjaran, NA, ACH, ARR; the Indonesia Endowment Fund for Education (LPDP), IM; and USAID through Sustainable Higher
Education Research Alliances -Centre for Collaborative Research on Acute Respiratory Infections Program to NA.

\section{AUTHORS' CONTRIBUTIONS}

NA, IM, and DHD designed the experimental study and carried out the analysis. NA, IM, ARR, and AC contributed in preparing the manuscript and revision. All authors have read and approved the final manuscript.

\section{CONFLICTS OF INTEREST}

The authors have none declare.

\section{REFERENCES}

1. Biswas B, Rogers K, McLaughlin F, Daniels D, Yadav A. Antimicrobial activities of leaf extracts of guava (Psidium guajava L.) on two gramnegative and gram-positive bacteria. Int J Microbiol 2013;2013:746165.

2. Daswani PG, Gholkar MS, Birdi TJ. Psidium guajava: A single plant for multiple health problems of rural Indian population. Pharmacogn Rev 2017;11:167-74.

3. Wu J, Wan Z, Yi J, Wu Y, Peng W, Wu J, et al. Investigation of the extracts from Bidens pilosa linn. var. radiata Sch. Bip. For antioxidant activities and cytotoxicity against human tumor cells. J Nat Med 2013;67:17-26.

4. Párraga I, López-Torres J, Andrés F, Navarro B, del Campo JM, GarcíaReyes M, et al. Effect of plant sterols on the lipid profile of patients with hypercholesterolaemia. Randomised, experimental study. BMC Complement Altern Med 2011;11:73.

5. Ekor M. The growing use of herbal medicines: Issues relating to adverse reactions and challenges in monitoring safety. Front Pharmacol 2014;4:177.

6. Erkekoglu P, Giray BK, Basaran N. 3R principle and alternative toxicity testing method. Fabad J Pharm Sci 2011;36:101-17.

7. OECD. Test No. 425: Acute Oral Toxicity: Up-and-Down Procedure, OECD Guidelines for the Testing of Chemical. Sec. 4. Paris: OECD Publishing; 2008. Available from: https://www.doi. org/10.1787/9789264071049-en. [Last accessed on 2017 Apr 03]

8. Subramanian K, Sankaramourthy D, Gunasekaran M. Toxicity studies related to medicinal plants. In: Natural Products and Drug Discovery. USA: Elsevier; 2018. p. 491-505.

9. Lobo VC, Phatak A, Chandra N. Acute toxicity studies of some Indian medicinal plants. Pharmacogn J 2010;2:207-10.

10. Harborne JB. Phytochemical Methods A Guide to Modern Techniques of Plant Analysis. $8^{\text {th }}$ ed. London: Chapman and Hall Ltd.; 1998.

11. Avriyanti E, Atik N, Kunii M, Furumoto N, Iwano T, Yoshimura S, et al. Functional redundancy of protein kinase D1 and protein kinase D2 in neuronal polarity. Neurosci Res 2015;95:12-20.

12. Avwioro G, Iyiola S, Aghoghovwia B. Histological and biochemical markers of the liver of wistar rats on subchronic oral administration of green tea. N Am J Med Sci 2010;2:376-80

13. Alturkistani HA, Tashkandi FM, Mohammedsaleh ZM. Histological stains: A Literature review and case study. Glob J Health Sci 2015;8:72-9

14. Venkatesan N, Thiyagarajan V, Narayanan S, Arul A, Raja S, Vijaya Kumar SG, et al. Anti-diarrhoeal potential of Asparagus racemosus wild root extracts in laboratory animals. J Pharm Pharm Sci 2005;8:39-46.

15. Qadan F, Thewaini AJ, Ali DA, Afifi R, Elkhawad A, Matalka KZ, et al. The antimicrobial activities of Psidium guajava and Juglans regia leaf extracts to acne-developing organisms. Am J Chin Med 2005:33:197-204.

16. Atik N, Munawir MD, Tarawifa S, Darmadji HP. Effect of guava extract administration on megakaryocytes amount in mice femur. Indone J Clin Pharm 2017;6:116-22.

17. Attawish A, Chavalittumrong P, Rugsamon P, Chuntapet P. Toxicity Study of Psidium guajava Linn. Leaves. Thailand: Ministry of Public Health; 1995. p. 289-305.

18. Jaiarj P, Khoohaswan P, Wongkrajang Y, Peungvicha P, Suriyawong P, Saraya ML, et al. Anticough and antimicrobial activities of Psidium guajava linn. Leaf extract. J Ethnopharmacol 1999;67:203-12.

19. Roy CK, Kamath JV, Asad M. Hepatoprotective activity of Psidium guajava linn. leaf extract. Indian J Exp Biol 2006;44:305-11.

20. Gorinstein S, Zemser M, Haruenkit R, Chuthakorn R, Grauer F, MartinBelloso $\mathrm{O}$, et al. Comparative content of total polyphenols and dietary fiber in tropical fruits and persimmon. J Nutr Biochem 1999;10:367-71.

21. You DH, Park JW, Yuk HG, Lee SC. Antioxidant and tyrosinase 
inhibitory activities of different parts of guava (Psidium guajava L.). Food Sci Biotechnol 2011;20:1095-100.

22. Yu K, Chen F, Li C. Absorption, disposition, and pharmacokinetics of saponins from Chinese medicinal herbs: What do we know and what do we need to know more? Curr Drug Metab 2012;13:577-98.

23. Muda I, Atik N. Profile of liver function in mice after high dose of Psidium guajava linn. extract treatment. Biomed Pharmacol J 2018;11:1397-401.

24. Atik N, Tarawifa S, Avriyanti E, Rahmadi AR, Hilmanto D. Psidium guajava L. extract increases platelet count through enhancement of stem cell factor expression in thrombocytopenic mice model. Int $\mathrm{J}$ Pharm Pharm Sci 2018;10:23-6.
25. Mohan M, Shashank B, Priya AV. Protective of Psidium guajava L. leaves ethanolic extract on doxorubin-induced nephrotoxicity in rats. Indian J Nat Prod Resour 2015;5:129-33.

26. Lin CY, Yin MC. Renal protective effects of extracts from guava fruit (Psidium guajava L.) in diabetic mice. Plant Foods Hum Nutr 2012;67:303-8

27. Zaltzman JS, Whiteside C, Cattran DC, Lopez FM, Logan AG. Accurate measurement of impaired glomerular filtration using single-dose oral cimetidine. Am J Kidney Dis 1996;27:504-11.

28. Askaripour MA, Tabatabaei SR, Hosseini F, Varzi HN. Effect of purslane (Portulaca oleracea) on renal ischemia/reperfusion injury in rat. Int J Pharm Pharm Sci 2015;7:467-71. 